\title{
THE RELEVANT TRENDS OF CROWDFUNDING AND PRACTICAL ASPECTS OF ITS DEVELOPMENT IN UKRAINE
}

\author{
Vasil Orlov; Galyna Otlyvanska; Anastasiia Haitan
}

\author{
O. S. Popov Odessa National Academy of Telecommunications, \\ Odessa, Ukraine
}

\begin{abstract}
Summary. The paper deals with the modern conditions of crowdfunding as a real possibility to finance start-ups in Ukraine. The objective of the paper is to define the relevant trends of crowdfunding worldwide and summarize practical aspects of its development in Ukraine. Method. The observation, comparison, generalization, grouping scientific methods are applied in the paper. Results. Crowdfunding is still growing in all regions of the world but due to its gradual saturation and growing popularity of others sources of funding such as cryptocurrency, analysts forecast the crowdfunding industry CAGR of over $17 \%$ from 2018 to 2022 in comparison with the early years (2012-2015) when it was about 200\%. The outlook is changing rapidly with the ongoing industry expansion. Two countries dominating the world's crowdfunding market are China and the United States. During the last years, P2P lending is the most popular crowdfunding type with a share of approximately $76 \%$. It is caused by the great high number of its advantages: the low-level costs of arranging loans; the independent decision of the investor; there are practically no failures; the principle of self-service; average loan rates are lower than online microloans; the personal data of clients is obscured. The examples demonstrate that P2P lending is in demand in Ukraine and can become widespread in the near future. It can be the first step to expand crowdfunding in Ukraine. World experience shows that Ukraine should also develop this industry. This will serve as a solid foundation for the development of small-and medium-sized businesses by attracting citizens' free funds. The demand for cheaper and affordable loans in countries with struggling economies is always high since bank loans are so expensive. The existing experience did not demonstrate the significant success in the development of $P 2 P$ lending in Ukraine. It is necessary to create the organizational and legislative framework for P $2 P$ successful implementation in Ukraine.
\end{abstract}

Key words: crowdfunding, peer-to-peer lending, conditions, tendency, advantages, disadvantages.

https://doi.org/10.33108/galicianvisnyk_tntu2019.06.014

Received 03.12.2019

УДК 338.42 : 330.322

\section{СУЧАСНІ ТЕНДЕНЦЇ̈ КРАУДФАНДИНГУ ТА ПРАКТИЧНІ АСПЕКТИ ЙОГО РОЗВИТКУ В УКРАЇНІ}

\author{
Василь Орлов; Галина Отливанська; Анастасія Гайтан
}

\section{Одеська національна академія зв’язку імені О. С. Попова, Одеса, Україна}

Резюме. Розглянуто сучасні умови ринку краудфандингу як реальну можливість фінансування стартапів в Украӥні. Метою статті є визначення актуальних тенденцій краудфандингу в усьому світі та узагальнення практичних аспектів його розвитку в Украӥні. Застосовано методи наукового пізнання, такі, як спостереження, порівняння, узагальнення, групування тощо. Ринок краудфандингу все ще зростає в усіх регіонах світу, але через його поступове насичення та зростаючу популярність інших ринків, таких, як ринок криптовалют, аналітики прогнозують, щзо з 2018 до 2022 року річний темп зростання краудфандингу складе приблизно 17\% порівняно з попередніми роками (2012-2015 роки), коли він становив близько 200\%. Ринок швидко змінюється та постійно розширюється. Дві краӥни домінують на світовому ринку краудфандингу - ие Китай та США. Протягом останніх років кредитування Р2P ие найпопулярніший тип краудфандингу з часткою ринку приблизно 76\%. Це зумовлено великою кількістю 
його переваг: низьким рівнем витрат на оформлення позик; самостійне рішення інвестора; при самостійному ріменні інвестора відмов практично немає; принцип самообслуговування; середні ставки позики нижчі, ніж онлайн-позики; особисті дані клієнтів закриті. Надані приклади демонструють, щяо кредитування Р2Р є затребуваним в Украйні та може набути значного поширення найближчим часом. Це стане першим кроком до розширення краудфандингу в Україні. Світовий досвід показує, щуо Україні також слід розвивати цеей ринок. Він послужить надійною основою для розвитку малого та середнього бізнесу шляхом залучення вільних коштів громадян. Попит на дешевші та доступні позики в країнах з проблемною економікою завжди високий, оскільки банківські кредити занадто дорогі. Існуючий досвід розвитку ринку P2P кредитування в Украӥні не показав значних успіхів $i$ потребує створення організачійної та законодавчої баз для успішної імплементації.

Ключові слова: краудфандинг, Р2Р кредитування, умови, тендениії, переваги, недоліки.

Introduction. Today, for the Ukrainian economy, the issue of attracting funds to startup and further develop a business has important significance. Existing ways of financing entrepreneurial activities are often unavailable in the early stages and generally have their disadvantages, such as investor dependence, pressure or high cost. The use of crowdfunding as a financing tool, which has appeared recently, today is very popular among venture investors and startups, as well as for the entire business community.

It is important to note that according to different resources [1-2], the global crowdfunding market was evaluated at approximately $\$ 55,07$ billion in 2017 . While in Ukraine, the IT industry, which is one of the largest in the Ukrainian market, attracted crowdfunding of only $\$ 10$ million [3]. The few domestic crowdfunding platforms «Spilnokosht», «NASTARTE», «GoFundEd» have not received sufficient development and are mainly focused on social, cultural and charitable projects [4]. Crowdfunding in Ukraine is at its initial stage. Therefore, there is considerable interest to study of crowdfunding to understand the possibilities of its expansion in Ukraine.

Review of the latest research and literature. In the last few years, the publications about crowdfunding have been actively appearing in Ukrainian science literature [5-8]. They research the issues of crowdfunding, its importance, advantages, and risks. Nevertheless, the questions to identify current global trends and summarize various aspects of crowdfunding practice remain relevant. It is important in this context to understand the current conditions, as well as create environments for the development of crowdfunding in Ukraine.

Main purpose of the article. The purpose of the article is to define the relevant trends of crowdfunding worldwide and summarize practical aspects of its development in Ukraine.

Task setting. These are the scientific tasks to achieve the purpose: summarize the relevant crowdfunding tendencies worldwide; generalize the features and practical aspects of peer-to-peer lending as a type of crowdfunding and make conclusions about its expansion in Ukraine.

Statements of main issues of the study. Crowdfunding is a type of collective financing. It means that a group of people finances initiatives of other people or organizations. The project can collect money through online donations or investments. The project managers can communicate through the Internet with thousands or millions of potential investors. Also, they often offer rewards in the form of services or products. However, donations may also be altruistic.

Crowdfunding projects can range from musical or artistic projects (for example getting money for a film) to political campaigns, debt financing, school construction or start-ups, etc. There are three types of crowdfunding: reward-based crowdfunding, equity-based crowdfunding, and peer to peer lending.

At the beginning of its formation, the global crowdfunding market showed incredible growth rates. Global crowdfunding increased from $\$ 2,7$ billion in 2012 to approximately $\$ 34,4$ 
billion in 2015 [9]. CAGR (Compound Annual Growth Rate) of the global crowdfunding market was estimated at over $200 \%$ for this period [4].

In order to understand why this financing tool became so popular, its advantages and disadvantages by types of crowdfunding participants should be considered (tab. 1).

Table 1

Advantages and disadvantages of crowdfunding by type of participants

\begin{tabular}{|c|c|c|}
\hline Participant & Advantages & Disadvantages \\
\hline $\begin{array}{c}\text { A founder of } \\
\text { a project }\end{array}$ & $\begin{array}{l}\text { - allows acquisition of money for } \\
\text { easy and fast financing; } \\
\text { - in many projects, it is not } \\
\text { necessary to return the money; } \\
\text { - avoid payment commitments } \\
\text { with banks; } \\
\text { - no matter the number of projects } \\
\text { or their quality; } \\
\text { - growth of trust from potential } \\
\text { investors and consumers' loyalty; } \\
\text { - independent estimation of the } \\
\text { project's relevance and future success }\end{array}$ & $\begin{array}{l}\text { - the platform usually charges a } \\
\text { commission for the amount received; } \\
\text { - money is often received via } \\
\text { PayPal which also charges a } \\
\text { commission; } \\
\text { - if the minimum necessary } \\
\text { investments aren't received, they will } \\
\text { be returned to investors; } \\
\text { - founder needs to show the } \\
\text { creative project that catches the eye; } \\
\text { - other companies that have the } \\
\text { necessary resources to make a new } \\
\text { project, can copy it in an early stage }\end{array}$ \\
\hline A backer & $\begin{array}{l}\text { - allows financing social projects } \\
\text { in small quantities that contribute to } \\
\text { the country's social development; } \\
\text { - allows obtaining new products or } \\
\text { participation in future companies; } \\
\text { - invest even a very small amount }\end{array}$ & $\begin{array}{l}\text { - backer can be cheated, so each } \\
\text { project should be carefully studied; } \\
\text { - backer needs to invest more for } \\
\text { better rewards }\end{array}$ \\
\hline
\end{tabular}

Source: [10].

It must be understood that crowdfunding does not give a $100 \%$ guarantee of getting benefits. No one knows whether this or that crowdfunding campaign will be successful. After all, the success of the campaign depends on many factors. Even the most thoughtful and competently presented idea may not interest sponsors

Current statistics show that the global crowdfunding growth is gradually decelerating. The year over year growth rate is estimated at $30.89 \%$ in 2018 . Technavio analysts forecast the global crowdfunding market to grow at a CAGR of over 17\% from 2018 to 2022. Incremental growth is evaluated at $\$ 89,72$ billion during the forecast period [2].

So, on the one hand, it can be supposed that the deceleration of global crowdfunding market growth is due to its gradual saturation. As well as the growing popularity of the cryptocurrency funding, particularly Initial Cryptocurrency Offering (ICO), etc. On the other hand, there is the opinion that crowdfunding activity is actively developing and shows no signs of slowing down [11].

It is important to note that, the global crowdfunding keeps growing and according to the analytic data indicate the still-growing popularity and prospects for its continued development [2]:

- global crowdfunding market is expected to show an annual growth rate (20192023 ) of $17 \%$ resulting in the total amount of US $\$ 144,79$ billion by 2025 ;

- the average funding per campaign in the Crowdfunding segment amounts to US \$794 in 2019; 
- the number of crowdfunding campaigns in 2019 is estimated at 8,724 thousand. In the Crowdfunding segment, the number of funding campaigns is expected to amount to 12,063 thousand by 2023 .

Crowdfunding statistics help illustrate the terrain that comes with what many refer to as the «democratization» of fundraising. There are thousands of crowdfunding platforms around the world. Kickstarter was launched on April 28, 2009, and for a long time has been recognized as the most successful. As of that time, the number of launched projects on Kickstarter amounted to 461,628, with the success rate among these projects amounting to $37.3 \%$. Kickstarter has had 319,051 completed projects - the most overall for any platform [12]. Today, the platform is successfully developing, and in October 2019 it raised US $\$ 4,681,766,941$ investments from 17,191,273 people from 224 countries. Moreover, about half of this amount has been collected over the past 2 years. It indicates a growing interest and confidence in such a method of financing as crowdfunding [13].

For a long time, North America has been a market leader in crowdfunding. The reason for this was the fact that in 2012, US President Barack Obama signed the JOBS Act (the Jumpstart Our Business Startups Act). Since then, crowdfunding has been permitted and regulated in the US.

The North American crowdfunding industry was valued at US $\$ 17,2$ billion in 2017. In second place was Asia - US \$10,54 billion and in third Europe - US \$6,48 billion. In 2017, 191 platforms were in the USA [14].

Today the USA is the dominant country in the America's region where it has a market share of $96.5 \%$. With a worldwide market share of approximately $10 \%$. The US is also the only real contender to China when looking at the global data. From the Americas region, especially Canada could be an interesting case in the following years as it is already placed as number 6 on the list with a funding volume of US $\$ 0,87$ billion and at the same time is experiencing high growth rates (159\% in 2017) [15].

The Chinese market only started in 2013. With the rapid rise of China's technology finance, the crowdfunding industry has developed rapidly in China. Since 2018, China has surpassed the United States to become the world's largest player.

China is the largest region of Crowdfunding in the world in the past few years and it will keep increasing in the next few years. China market took up about $37 \%$ of the global market in 2018 [16]. Chinese authorities are still in the midst of enforcing a stricter regulation on crowdfunding platforms with a special focus on peer-to-peer lending.

So, what is peer-to-peer lending (P2P) and how does it differs from other types of crowdfunding? P2P means person-to-person loans. It is the type of money lending in that a group of people invest money in a business or in an individual.

Peer to peer lending is an offshoot of crowdfunding as well as crowdinvesting. It has the financial type of participants' motivation and requires special activities regulation. Also, $\mathrm{P} 2 \mathrm{P}$ lending is focused on the interest guarantee for the borrower, the money transfer confirmation for the borrower and reduction of the scam possibility.

Ukraine has also taken the path of P2P lending developing and by 2019 get some experience. It is due to peer-to-peer lending being the largest type of crowdfunding. Its market share was approximately $75 \%$ in 2017. This value has remained stable for 3 years. According to Morgan Stanley's company, the P2P lending industry will grow significantly [17].

Since 2016, when small business has been increasingly approached for peer-to-peer lending, this financial sector has started to grow rapidly - by 53\% annually. Now analysts are talking about $120 \%$ of the average annual increase. And the reasons for the stop have not yet been observed [17].

In the table 2 is considered the difference between P2P lending and other types of crowdfunding. 
Table 2

The difference between P2P lending and other types of crowdfunding

\begin{tabular}{|c|c|c|c|}
\hline Features & $\begin{array}{c}\text { Rewards-Bases } \\
\text { crowdfunding }\end{array}$ & $\begin{array}{c}\text { Equity-Based } \\
\text { crowdfunding }\end{array}$ & P2P Lending \\
\hline Cost & $\begin{array}{c}\text { Low-medium } \\
\text { (Time + Cost to produce } \\
\text { rewards) }\end{array}$ & $\begin{array}{c}\text { High } \\
\text { (Equity) }\end{array}$ & $\begin{array}{c}\text { Medium } \\
\text { (Interest, most } \\
\text { platforms are } \\
\text { competitive) }\end{array}$ \\
\hline Reward & Low-High & Medium-High & Medium-High \\
\hline $\begin{array}{c}\text { Investment } \\
\text { model }\end{array}$ & $\begin{array}{c}\text { 1-Time backers who } \\
\text { receive rewards in } \\
\text { exchange for helping get } \\
\text { you off the ground }\end{array}$ & $\begin{array}{c}\text { Lifetime investors } \\
\text { who own a stake in } \\
\text { your company }\end{array}$ & $\begin{array}{c}\text { Lenders for the duration } \\
\text { of the loan who collect } \\
\text { interest in exchange for } \\
\text { their investment }\end{array}$ \\
\hline
\end{tabular}

Source: [18].

All of these crowdfunding methods differ in their way of obtaining funds, type of reward and type of cost. The advantage of P2P lending is the ability to become a participant in the capital market even with a small amount of funds. At the same time, this method is highly profitable.

Since almost everyone who has been refused by other organizations can get credit, lenders have the right to raise interest rates for using money, which makes P2P lending a profitable investment tool. The advantages of this method are described in more detail below.

The lender and the borrower find each other on special websites for online lending. The Internet service acts as an intermediary and partly assumes the function of a bank, as it enables people who have free money to invest with guaranteed interest and at the same time to help someone. The difference with banks is that people agree on the amount of debt, interest and repayment period.

Prosper was the first digital P2P lending platform that was launched in 2005 in the United States. Later similar online services began to appear in other countries. The first sites had many disadvantages, were too risky for investors, and had a significant percentage of defaults.

Since then, customer selection mechanisms have been continuously improved. Additional guarantee funds are created, investment insurance is used. Investors get more information about applicants than they did before.

Small wonder that P2P lending became so popular. It is one of the shortest ways to get money from the investor to the borrower due to its advantages $[6,18,19]$ :

- as a result of a most operations automation, the costs of arranging loans decreased;

- an independent decision of the investor about which borrower or the project must be funded;

- there are practically no failures, even a bad credit history and outstanding debts do not often cause a failure; time and money;

- the principle of self-service, simplicity and a minimum of documents means saving

- average loan rates are lower than online microloans;

- personal data of clients is closed for viewing. Reliable media and information protection systems guarantee their safe storage. 
In Ukraine, «Privat Bank» first attempted this financial instrument. The service started briskly. In June 2016, the management of «Privat Bank» reported that the P2P platform generated loans for UAH1, 6 billion. However, in the end, it was not successful because the national regulator determined that the activity of the bank was not fully clear and so banned it [20].

There is also the Taplend mobile app. It allows money to be borrowed from individuals. Nevertheless, there are questions about this. Firstly, it allows only acquaintances to be notified of its request, greatly restricting the list of possible investors. Secondly, the service does not allow you to create a P2P loan application with a proposal to pay interest on the loan, which could provide motivation. In fact, Taplend simply offers the opportunity to borrow from friends, but in a somewhat intricate way.

The first real P2P lending service in Ukraine is FinHab. The service is still little known but now almost all loan applications find their investors. There is no clearly established interest rate on the loan. Each application for a loan is tested and as a result, it is assigned an individual rate.

To sum, the examples demonstrate that $\mathrm{P} 2 \mathrm{P}$ lending is in demand in Ukraine and can become even more widespread in the near future. It can be the first step to expand crowdfunding with the financial type of motivation in Ukraine.

Conclusions. The latest data available on the worldwide show that the crowdfunding market is still growing in all regions of the world. But due to its gradual saturation and growing popularity of other markets such as the cryptocurrency market, analysts forecast the crowdfunding industry CAGR of over $17 \%$ from 2018 to 2022 in comparison with the early years (2012-2015) when it was about 200\%.

The outlook is changing rapidly with the ongoing industry expansion. Two countries dominating the world's crowdfunding industry are China and the United States. During the last few years, P2P lending has been the most popular crowdfunding type with a share of approximately $76 \%$. This is due to the great number of its advantages.

World experience shows that Ukraine should also develop this industry. This will serve as a solid foundation for the development of small- and medium-sized businesses by attracting citizens' free funds. The demand for cheaper and affordable loans in countries with struggling economies is always high since bank loans are so expensive.

Unfortunately, the existing Ukrainian experience did not demonstrate the significant success in $\mathrm{P} 2 \mathrm{P}$ lending development. Based on this fact, it can be concluded that it is necessary to create the organizational and legislative framework for the successful P2P implementation in Ukraine. It should be focused on the rate and interest guarantee questions as well as on the money transfer confirmation for the borrower and reduction of the scam possibility.

\section{References}

1. Global Crowdfunding Market 2018-2022. USD 89, 72. Billion Incremental Growth over the Next Five Years. Technavio. URL: https://www.businesswire.com/news/home/20190719005135/en/GlobalCrowdfunding-Market-2018-2022-USD-89.72-Billion_(accessed 25.11.2019). [In English].

2. Crowdfunding Industr y set to grow according to forecasts. URL: https://www.whatech.com/marketresearch/industrial/598706-crowdfunding-industry-by-2025-major-market-players-gofundme-indiegogokickstarter-patreon-teespring-tilt-circle-up-angel-list (accessed 24.11.2019). [In English].

3. Sychikova Y., Sysoyev Y. The dealbook of Ukraine. Ultimate report on Ukraine's Venture Investment IT Industry. 2018. URL: https://www.slideshare.net/YevgenSysoyev/the-dealbook-of-ukraine-2018-edition (accessed 24.11.2019). [In English]. 
4. Otlyvanska G. Investytsiyna diyal'nist' telekomunikatsiynoho pidpryyemstva: teoriya ta praktyka: monohrafiya. Odesa: FOP Bondarenko M. O. 2019. [In Ukrainian].

5. Azarenkova H. M., Mel'nykova N. S., Ohorodnyk V. V. Analyz osobennostey kraudfandynha kak sposoba pryvlechenyya sredstv $\mathrm{v}$ fynansovыy proekt nachynayushchykh predprynymateley. Instytutsiynyy repozytariy DVNZ "Universytet bankivs'koyi spravy". URL: http://dspace.ubs.edu.ua/ jspui/bitstream/123456789/1422/1/azarenkova_the_analysis.pdf (accessed 20.11.2019). [In Russian].

6. Apal'kov S. S. Investytsiyni ryzyky na svitovomu rynku al'ternatyvnoho finansuvannya Ekonomichnyy prostir. 2018. No. 137. P. 5-16. URL: http://srd.pgasa.dp.ua:8080/xmlui/handle/123456789/872 (accessed 20.11.2019). [In Ukrainian].

7. Oksenyuk K. I. Kraudfandynh - suchasnyy instrument finansuvannya. Ekonomichni nauky: zbirnyk naukovykh prats' Luts'koho natsional'noho tekhnichnoho universytetu. Seriya "Rehional'na ekonomika". 2017. No. 14 (55). P. 232-238. [In Ukrainian].

8. Shevchenko O. M., Kazak O. O. Rozvytok kraudfandynhu v umovakh tsyfrovoyi transformatsiyi ekonomiky Ukrayiny. Efektyvna ekonomika. 2019. No. 3. URL: http://www.economy.nayka.com.ua/? op=1\&z=6957. https://doi.org/10.32702/2307-2105-2019.3.43.

9. Massolution Crowdfunding Industry 2015. URL: http://crowdexpert.com/crowdfunding-industry-statistics/ (accessed 24.11.2019). [In English].

10. P2P-lending. URL: https://financer.com/ua/zaoshhadzhennya-ta-investyciyi/p2p-kredytuvannja/ (accessed 24.11.2019). [In Ukrainian].

11. Okhrimenko O. 8 crowdfunding trends you need to know in 2019. URL: https://justcoded.com/blog/8crowdfunding-trends-you-need-to-knowl (accessed 23.11.2019). [In English]. https://doi.org/10.12968/sece.2019.8.11

12. Shepherd Maddie Crowdfunding Statistics: Overview. URL: https://www.fundera.com/resources/ crowdfunding-statistics (accessed 20.11.2019). [In English].

13. Stats. URL: https://www.kickstarter.com/help/stats (accessed 27.11.2019). [In English].

14. Crowdfunding statistics. URL: https://blog.fundly.com/crowdfunding-statistics/ (accessed 20.11.2019). [In English].

15. Crowdfunding Market 2019. Global Industry Size, Share, Demands, Growth Analysis, Company Profiles, Revenue and Forecast 2024. URL: https://www.rfdtv.com/story/40787592/crowdfunding-market-2019global-industry-size-share-demands-growth-analysis-company-profiles-revenue-and-forecast-2024 (дата звернення: 27.11.2019).

16. Crowdfunding Statistics Worldwide: Volume by Country and Industry Trends. URL: https://p2pmarketdata.com/crowdfunding-statistics-worldwide/(accessed 27.11.2019). [In English].

17. V Ukrayini z"yavylasya persha platforma P2P-kredytuvannya. URL: https://news.finance.ua/ua/news//420417/v-ukrayini-zyavylasya-persha-platforma-p2p-kredytuvannya (accessed 24.11.2019). [In Ukrainian].

18. Crowdfunding and Peer-to-Peer Lending: Everything You Need to Know. URL: https: //www.excelcapmanagement.com/crowdfunding-peer-to-peer-lending/ (accessed 27.11.2019). [In English].

19. P2P lending. URL: https://financer.com/ua/zaoshhadzhennya-ta-investyciyi/p2p-kredytuvannja/ (accessed 27.11.2019). [In English].

20. Ryabukha A. P2P lending. URL: https://finance.ua/ua/credits/r2r-kreditovanie_(accessed 27.11.2019). [In English].

\section{Список використаної літератури}

1. Global Crowdfunding Market 2018-2022. USD 89, 72. Billion Incremental Growth over the Next Five Years. Technavio. URL: https://www.businesswire.com/news/home/20190719005135/en/GlobalCrowdfunding-Market-2018-2022-USD-89.72-Billion (дата звернення: 25.11.2019).

2. Crowdfunding Industr y set to grow according to forecasts. URL: https://www.whatech.com/marketresearch/industrial/598706-crowdfunding-industry-by-2025-major-market-players-gofundme-indiegogokickstarter-patreon-teespring-tilt-circle-up-angel-list (дата звернення: 24.11.2019).

3. Sychikova Y., Sysoyev Y. The dealbook of Ukraine. Ultimate report on Ukraine's Venture Investment IT Industry. 2018. URL: https://www.slideshare.net/YevgenSysoyev/the-dealbook-of-ukraine-2018-edition (дата звернення 24.11.2019). 
4. Отливанська Г. А. Інвестиційна діяльність телекомунікаційного підприємства: теорія та практика: монографія. Одеса: ФОП Бондаренко М. О., 2019. 408 с.

5. Азаренкова Г. М., Мельникова Н. С., Огородник В. В. Анализ особенностей краудфандинга как способа привлечения средств в финансовый проект начинающих предпринимателей. Інституційний репозитарій ДВНЗ «Університет банківської справи». URL: http://dspace.ubs.edu.ua/ jspui/bitstream/123456789/1422/1/azarenkova_the_analysis.pdf (дата звернення: 12.11.2019).

6. Апальков С. С. Інвестиційні ризики на світовому ринку альтернативного фінансування Економічний простір. 2018. № 137. С. 5-16. URL: http://srd.pgasa.dp.ua:8080/xmlui/handle/ 123456789/872 (дата звернення: 12.11.2019).

7. Оксенюк К. І. Краудфандинг - сучасний інструмент фінансування. Економічні науки: збірник наукових праць Луцького національного технічного університету. Серія «Регіональна економіка». 2017. Випуск 14 (55). С. 232-238.

8. Шевченко О. М., Казак О. О. Розвиток краудфандингу в умовах цифрової трансформації економіки України. Ефективна економіка. 2019. № 3. URL: http://www.economy.nayka.com.ua/?op=1\&z=6957 https://doi.org/10.32702/2307-2105-2019.3.43.

9. Massolution Crowdfunding Industry 2015. URL: http://crowdexpert.com/crowdfunding-industry-statistics/ (дата звернення: 24.11.2019).

10. Кредитування P2P. URL: https://financer.com/ua/zaoshhadzhennya-ta-investyciyi/p2p-kredytuvannja/ (дата звернення: 24.11.2019).

11. Okhrimenko O. 8 crowdfunding trends you need to know in 2019. URL: https://justcoded.com/blog/8crowdfunding-trends-you-need-to-know/ https://doi.org/10.12968/sece.2019.8.11

12. Shepherd Maddie Crowdfunding Statistics: Overview. URL: https://www.fundera.com/resources/ crowdfunding-statistics (дата звернення: 20.11.2019).

13. Stats. URL: https://www.kickstarter.com/help/stats (дата звернення: 27.11.2019).

14. Crowdfunding statistics. URL: https://blog.fundly.com/crowdfunding-statistics/ (дата звернення: 20.11.2019).

15. Crowdfunding Market 2019. Global Industry Size, Share, Demands, Growth Analysis, Company Profiles, Revenue and Forecast 2024. URL: https://www.rfdtv.com/story/40787592/crowdfunding-market-2019global-industry-size-share-demands-growth-analysis-company-profiles-revenue-and-forecast-2024 (дата звернення: 27.11.2019).

16. Crowdfunding Statistics Worldwide: Volume by Country and Industry Trends. URL: https: //p2pmarketdata.com/crowdfunding-statistics-worldwide/ (дата звернення: 27.11.2019).

17. В Україні з'явилася перша платформа P2P-кредитування. URL: https://news.finance.ua/ua/news//420417/v-ukrayini-zyavylasya-persha-platforma-p2p-kredytuvannya (дата звернення 24.11.2019).

18. Crowdfunding and Peer-to-Peer Lending: Everything You Need to Know. URL: https: //www.excelcapmanagement.com/crowdfunding-peer-to-peer-lending/ (дата звернення: 27.11.2019).

19.P2P lending. URL: https://financer.com/ua/zaoshhadzhennya-ta-investyciyi/p2p-kredytuvannja/ (дата звернення: 27.11.2019).

20. Ryabukha A. P2P lending. URL: https://finance.ua/ua/credits/r2r-kreditovanie (дата звернення: 27.11.2019). 